\title{
MAKNA 1 TIMOTIUS 4:12 DAN PENERAPANNYA BAGI GENERASI Z
}

\author{
Adi Putra
}

\section{Pendahuluan}

Siapakah generasi Z? Generasi Z adalah generasi yang lahir dalam kurun waktu tahun 1995-2010. Generasi ini merupakan generasi peralihan dari generasi Y dengan kondisi teknologi yang semakin berkembang. Itulah sebabnya, generasi ini juga seringkali disebut iGeneration atau generasi net atau generasi internet. Sekalipun tidak jauh berbeda dengan generasi sebelumnya, yakni generasi Y; akan tetapi generasi $\mathrm{Z}$ mampu mengaplikasikan semua kegiatan dalam satu waktu seperti nge-tweet menggunakan smartphone, browsing dengan komputer, hingga mendengarkan musik dengan headset. Mayoritas aktivitas yang dilakukan oleh generasi $\mathrm{Z}$ selalu bersinggungan dengan dunia maya. Bahkan sejak kecil, generasi ini telah mengenal dengan teknologi bahkan akrab dengan gadget yang canggih yang secara tidak langsung berpengaruh kepada kepribadian mereka. ${ }^{1}$

Terdapat bermacam-macam definisi rentang umur dari generasi Z Misalnya pada tahun 2012, seorang jurnalis bernama Bruce Horovitz mengatakan bahwa generasi Z memiliki rentang umur yang digunakan masih belum jelas. Akan tetapi Badan Statistik Kanada menghitung generasi Z mulai dari anak-anak yang lahir pada 1993 sampai pada tahun 2011. Kemudian McCrindle Research Centre di Australia menyebut Generasi Z sebagai orangorang yang lahir pada tahun 1995 sampai 2009. ${ }^{2}$ Terlepas dari perbedaan definisi rentang waktu kelahiran generasi Z, satu hal yang perlu digarisbawahi adalah generasi $\mathrm{Z}$ adalah orang-orang yang lahir di generasi internet atau generasi yang telah menikmati keajaiban teknologi usai kelahiran internet.

Sebagai generasi yang lahir pada era digital, akses internet telah menjadi kebutuhan bagi Generasi Z. Apabila lima tahun lalu, Warung Internet (Warnet) merupakan tempat utama bagi anak-anak (81\%) dan remaja (56\%) untuk mengakses internet. Akan tetapi sekarang, Warnet telah digantikan oleh rumah, di mana 49\% anak-anak dan 62\% remaja mengakses internet dari rumah mereka. Angka tersebut telah mengalami peningkatan dari 7\% pada anak-anak dan 9\% pada remaja. Artinya, terdapat 93\% anak-anak dan 97\% remaja menyatakan mengakses internet melalui smartphone atau iPad milik mereka. Hal yang mencengangkan berdasarkan survey yang dilakukan oleh Nielsen bahwa aktivitas yang paling banyak dilakukan oleh Generasi Z lewat internet adalah berinteraksi melalui media sosial, menjelajah internet, bermain game dan mendengarkan musik. ${ }^{3}$

\footnotetext{
${ }^{1}$ Natali Yustisia, “Teori Generasi,” Perbanas Institute, last modified 2016, accessed July 9 , 2021, https://dosen.perbanas.id/teori-generasi/.

${ }^{2}$ Aulia Adam, "Selamat Tinggal Generasi Milenial, Selamat Datang Generasi Z," Tirto.Id, last modified 2017, accessed July 9, 2021, https://tirto.id/selamat-tinggal-generasi-milenial.

3 "GEN Z: KONSUMEN POTENSIAL MASA DEPAN," Nielsen.Com, last modified 2016, accessed July 9, 2021, https://www.nielsen.com/id/en/press-releases/2016/GEN-ZKONSUMEN-POTENSIAI-MASA-DEPAN/.
} 
Selain itu, hasil survey yang dilakukan oleh Nielsen di 11 kota menunjukkan data bahwa generasi $\mathrm{Z}$ adalah pengunjung bioskop yang setia. Rata-rata mereka pergi ke bioskop 9 kali dalam satu tahun, dan remaja 11 kali dalam satu tahun. Artinya, hampir setiap bulan mereka pergi menonton di bioskop. Hasil survey ini juga menunjukkan bahwa olahraga merupakan kegiatan yang paling disukai anak-anak (48\%) dan remaja (44\%). Kegiatan berikutnya yang paling disukai adalah menonton TV oleh 38\% pada anak-anak dan 32\% pada remaja, dan mendengarkan musik oleh 17\% pada anak-anak dan 25\% pada remaja. Kemudian 11\% anak-anak menyatakan bahwa kegiatan yang mereka suka setelah mendengarkan musik adalah membaca buku. Sementara itu, setelah mendengarkan musik, remaja lebih suka menjelajah internet (17\%). ${ }^{4}$

Berikut ini terdapat beberapa ciri khas atau karakteristik dari generasi $\mathrm{Z}$ yang cukup mengkuatirkan apabila tidak mendapat pengawasan dari orangtua atau lingkungan keluarga dan gereja. Pertama, Merupakan generasi digital yang mahir dan gandrung akan teknologi informasi dan berbagai aplikasi komputer. Kedua, sangat suka dan sering berkomunikasi dengan semua kalangan khususnya lewat jejaring sosial seperti facebook, twitter, line, whatsapp, telegram, instagram, atau SMS. Ketiga, menempatkan uang dan pekerjaan dalam daftar prioritas. Keempat, cenderung kurang dalam berkomunikasi secara verbal, cenderung egosentris dan individualis, cenderung ingin serba instan, tidak sabaran, dan tidak menghargai proses. Kelima, Generasi Z benar-benar generasi pertama dunia digital. Smartphone dan media sosial tidak dilihat sebagai perangkat dan platform, tapi lebih pada cara hidup. ${ }^{5}$

Apabila memperhatikan uraian panjang lebar di atas tentang ciri khas dan karakteristik dari generasi Z, maka dapat dilihat sisi positif dan juga sisi negatifnya. Sisi positif memperlihatkan bahwa generasi ini dapat menjadi generasi penerus gereja dan keluarga untuk beradaptasi dengan perkembangan teknologi. Sehingga gereja dapat menyesuaikan diri dengan lebih baik dan tentunya melalui bantuan generasi $\mathrm{Z}$ ini. Akan tetapi, sisi negatif juga sangat berbahaya. Oleh karena generasi ini cenderung individualistik, cenderung egois, bahkan akses langsungnya kepada dunia internet juga menjadi titik poin yang "berbahaya" apabila tidak dikontrol dan diawasi oleh orangtua.

Seperti yang dikatakan Yunardi Kristian Zega, "Oleh karena itu, menanamkan kecerdasan spiritual pada anak usia remaja merupakan waktu yang sangat tepat. Dengan membekali dan meletakkan fondasi keimanan yang kokoh, menghasilkan remaja yang tidak menjadi angkuh dan melupakan Tuhan akibat pengaruh kemajuan teknologi dan internet yang semakin canggih saat ini". ${ }^{6}$ Untuk itulah penting bagi gereja dan keluarga membangun benteng spiritual yang kokoh bagi anak generasi Z guna membentuk kerohanian, iman, karakter dan moral mereka.

Melalui penelitian ini, disodorkan teks dalam 1 Timotius 4:12 untuk menjadi acuan, landasan bagi orangtua dan gereja bahkan anak generasi $\mathrm{Z}$ untuk introspeksi diri guna menjadikan mereka generasi masa depan gereja yang cemerlang. Sama halnya Rasul Paulus menasihatkan anak rohaninya yang juga

\footnotetext{
${ }^{4}$ Ibid.

5 “Generasi Z," Wikipedia, last modified 2020, accessed July 9, 2021, https://id.wikipedia.org/wiki/Generasi_Z.

${ }^{6}$ Yunardi Kristian Zega, "Pendidikan Agama Kristen Dalam Keluarga: Upaya Membangun Spiritualitas Remaja Generasi Z," JURNAL LUXNOS 7, no. 1 (2021): 105-116.
} 
masih sangat muda pada zamannya untuk menjadi teladan bagi orang-orang percaya, dalam perkataan, tingkah laku, kasih, dalam kesetiaan dan kesucian. Sehingga Timotius pun tidak kemudian dipandang atau dianggap rendah. Hal inipun perlu untuk ditanamkan bagi anak generasi $\mathrm{Z}$ supaya mereka tidak terjerumus ke dalam kejahatan yang dapat menghancurkan kehidupan mereka.

Apakah arti atau makna teks 1 Timotius 4:12 bagi generasi Z? Inilah yang menjadi fokus dari penelitian untuk menemukan maknanya untuk selanjutnya diaplikasikan ke dalam kehidupan generasi Z.

\section{Metode Penelitian}

Penelitian ini menggunakan metode kualitatif. Di mana menitikberatkan kepada kajian pustaka atau literatur untuk mengumpulkan, menganalisis hingga mensintesiskan data. Sehingga melaluinya, diharapkan dapat menemukan data atau informasi terbarukan perihal generasi $\mathrm{Z}$ dalam kaitannya dengan keteladanan yang harus diperlihatkan sesuai dengan apa yang termaktub dalam 1 Timotius 4:12.

\section{Pembahasan dan Hasil}

\section{A. Studi Apparatus 1 Timotius 4:12}

Berdasarkan informasi yang tercatat pada catatan kaki NA28, maka di sana terdapat catatan apparatus atau varian bunyi untuk 1 Timotius 4:12. Tepatnya,

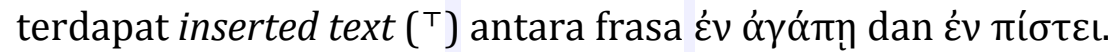

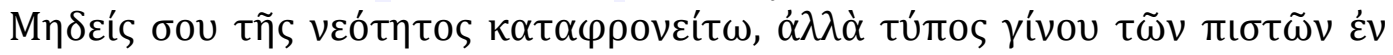

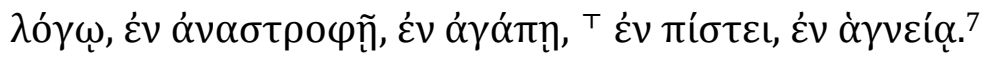

Penjelasan Apparatus. Beberapa manuskrip seperti manuskrip uncial kodeks Mosquensis (K), kodeks Angelicus (L), kodeks Porphyrianus (P), dan beberapa manuskrip minuscul, seperti: minuscul 365, 630, dan 1241

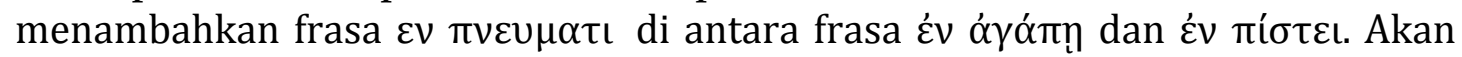
tetapi NA28 yang tanpa inserted text didukung oleh manuskrip-manuskrip, seperti: kodeks Sinaiticus (א), kodeks Alexandrinus (A), kodeks Ephraemi (C), kodeks Claromontanus (D), kodeks Augiensis (F), kodeks Boernerianus (G), kodeks Freerianus (I), kodeks Athous Lavrensis ( $\Psi)$, beberapa manuskrip minuscul, seperti: minuscul 6, 33, 81, 104, 629, 1175, 1505, 1739, 1881, serta representasi Tradisi Latin yang sama dengan bacaan Yunani (latt), Traidisi Syria (sy), versi Coptic (co) dan tulisan Bapa-bapa Gereja, dalam hal ini tulisan Clement dari Alexandria $(\mathrm{Cl}) .8$

Komentar dan Penilaian. Apabila memperhatikan manuskrip-manuskrip yang menambahkan frasa $\varepsilon v \pi v \varepsilon v \mu \alpha \tau \iota$ pada ayat 12 memiliki banyak kelemahan, terutama dari segi usia dan karakter. Kodeks Mosquensis (K), kodeks Angelicus (L), kodeks Porphyrianus (P) diprediksi ditulis sekitar abad ke-9 M - di mana menunjukkan usia yang masih sangat mudah. Bahkan untuk kodeks Mosquensis (K) dan kodeks Angelicus (L) hanya masuk kategori ke-5 teks Byzantine, sedangkan kodeks Porphyrianus tergolong ke dalam kategori ke-3 saja. Sama

7 Bruce M. Metzger Barbara Aland, Kurt Aland, Johannes Karavidopoulos, Carlo M. Martini, ed., Novum Testamentum Graece, 28th ed. (Stuttgart, Germany: Deutsche Bibelgesellschaft, 2012).

8 Ibid. 
seperti yang diketahui bahwa tipe teks Byzantine merupakan perkembangan kemudian yang umumnya didasarkan pada manuskrip-manuskrip Barat dan Alexandria. ${ }^{9}$ Popularitasnya sebagai teks yang paling disukai para penyalin pada Awal Abad Pertengahan karena tradisi teks Byzantine telah berusaha menggabungkan teks-teks terdahulu dengan memperluas teks dan memperhalus kata-kata yang sukar. ${ }^{10}$ Akan tetapi justru hal inilah yang membuat tipe teks Byzantine memiliki kualitas di bawah tipe teks Alexandria dan Barat. Sehingga dalam studi apparatus, teks Byzantine dianggap memiliki kualitas lebih rendah dari dua tipe teks yang lain. Kelemahan selanjutnya dari manuskrip-manuskrip yang menambahkan frasa $\varepsilon v \pi v \varepsilon v \mu \alpha \tau \iota$ adalah persebarahan geografisnya yang cakupannya tidak seluas dengan persebaran manuskrip yang mendukung versi NA28.

Selanjutnya beralih kepada manuskrip-manuskrip yang mendukung versi NA28 yang tanpa inserted text frasa $\varepsilon v \pi v \varepsilon v \mu \alpha \tau$. Apabila memperhatikan manuskrip kodeks uncialnya, maka cenderung lebih berkualitas dari manuskrip yang mendukung adanya frasa tambahan. Misalnya saja, kodeks Sinaiticus $(\kappa)$ yang diyakini ditulis abad ke-4 M, kodeks Alexandrinus (A) ditulis abad ke-5 M., kodeks Ephraemi (C) ditulis pada abad ke-5 M., kodeks Claromontanus (D) ditulis pada abad ke-6 M., kodeks Augiensis (F) ditulis pada abad ke-9, kodeks Boernerianus (G) ditulis pada abad ke-9 M., kodeks Freerianus (I) ditulis pada abad ke-5 M, kodeks Athous Lavrensis $(\Psi)$ ditulis sekitar abad ke-9/10M. Sekalipun ada beberapa kodeks yang usianya lebih mudah karena disalin sekitar abad ke-9 dan 10, namun kehadiran beberapa kodeks yang usia tua (karena ditulis abad ke-4, 5, dan 6) mengindikasikan bahwa versi NA28 dari segi usia dan karakter jauh lebih baik dan berkualitas apabila dibandingkan dengan manuskrip yang mendukung inserted text.

Kemudian, apabila memperhatikan semua kodeks yang mendukung teks NA28 maka mayoritas masuk ke dalam tipe teks Alexandria. Misalnya, kodeks Sinaiticus yang masuk kategori 1 (Pertama) teks Alexrandria, kodeks Ephraemi masuk kategori ke-2 (Kedua) teks Alexandria Akhir, dan kodeks Freerianus tergolong ke dalam kategori ke-2 (Kedua) teks Mesir (sama dengan teks Alexandria). Sehingga apabila dibandingkan dengan manuskrip yang mendukung inserted text maka apabila dinilai dari persepktif kebersamaan genealogis maka teks NA28 jauh lebih baik, lebih berkualitas.

Selanjutnya dalam hal persebaran geografis, manuskrip yang mendukung teks NA28 juga cenderung cakupannya sangat luas. Oleh karena menyebar mulai dari Mesir, Barat, hingga ke Syria. Hal itu terlihat dari dukungan varian ini dari Tradisi Latin (latt), Traidisi Syria (sy), versi Coptic (co) dan tulisan Bapa-bapa Gereja, dalam hal ini tulisan Clement dari Alexandria (Cl).

Dengan demikian, teks NA28 merupakan varian terbaik apabila dibanding dengan varian yang menambahkan frasa $\varepsilon v \pi v \varepsilon v \mu \alpha \tau$. Sehingga dalam kajian ini akan didasarkan kepada teks NA28. Kesimpulan ini juga diperkuat oleh pendapat dari Bruce M. Metzger yang mengatakan, perharps under the influence of Col. 1.8, after $\alpha \gamma \alpha \dot{\pi} \eta \eta$ the Textus Receptus inserts $\varepsilon \nu \pi v \varepsilon v \mu \alpha \tau$, with K L P most

${ }^{9}$ Daniel B. Wallace J. Ed. Komoszewski, M.James Sawyer, Reinventing Jesus: Bagaimana Para Pemikir Skeptis Keliru Memahami Yesus Dan Menyesatkan Budaya Populer (Jakarta: Perkantas, 2011), 104.

10 Jennifer Foutz Markley Craig L. Blomberg, New Testament Exegesis: Panduan Komprehensif Eksegesis Kitab-Kitab Perjanjian Baru (Malang: Gandum Mas, 2018). 
minuscules John Damascus Theodoret. The shorter reading is strongly supported by the best representatives of both Alexandrian and the Western text types ( $\mathrm{A}$ C D F G 33104 it $^{\text {d.g }}$ vg syr ${ }^{\text {p.h }}$ cop $^{\text {sa.bo }}$ goth arm eth). ${ }^{11}$

\section{B. Analisis dan Sintaksis teks 1 Timotius 4:12}

Apabila memperhatikan struktur kalimat dan kata termasuk gramatikal setiap kata (teks Yunaninya) dalam 1 Timotius 4:12, maka diperoleh terdapat

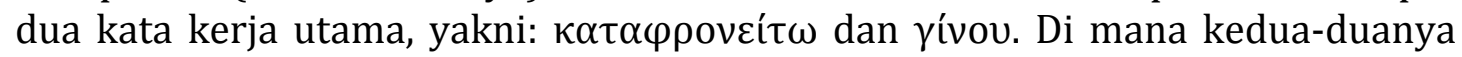
merupakan verba imperatif. Sehingga berdasarkan hal itu, ayat 12 ini dapat

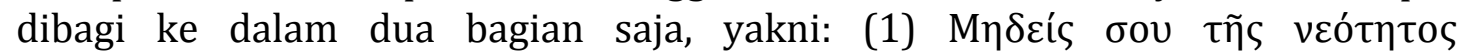

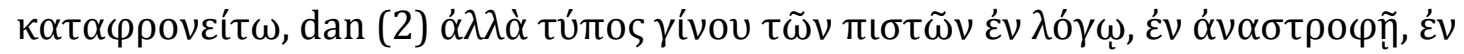

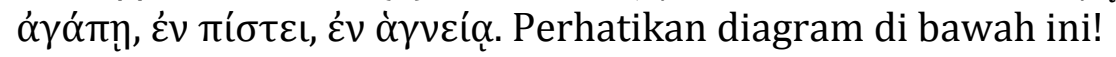

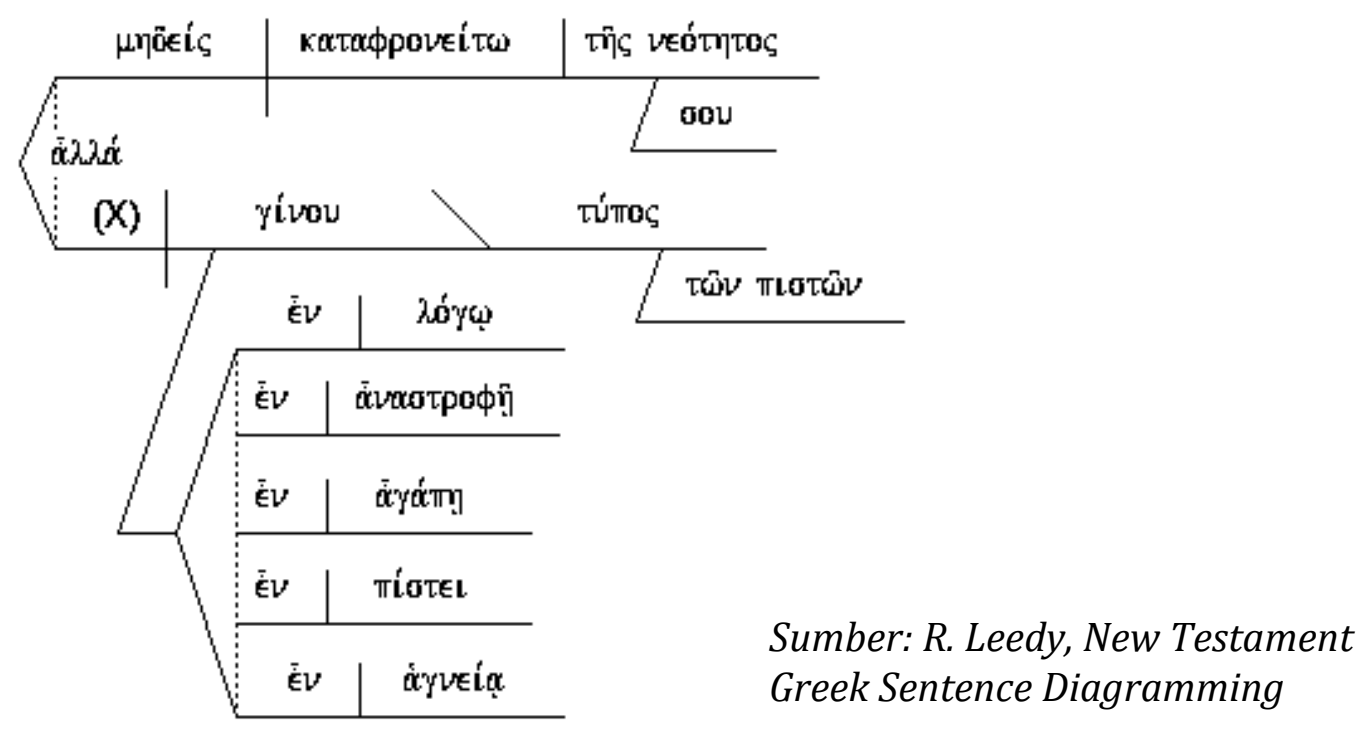

Dengan demikian, bagian pertama dari ayat 12 ini adalah "janganlah dia memandang rendah masa mudamu". Kemudian, bagian kedua adalah "jadilah contoh orang-orang percaya dalam dalam perkataan, dalam tingkah laku, dalam kasih, dalam kesetiaan, dalam kesucian". Yang menarik apabila memperhatikan diagram di atas, ungkapan "dalam perkataan, dalam tingkah laku, dalam kasih, dalam kesetiaan dan dalam kekudusan" bergantung langsung kepada frasa kamu jadilah contoh. Dengan demikian, hal ini akan sangat signifikan dalam penafsiran bagian ini.

\section{Tafsiran 1 Timotius 4:12}

Seperti halnya pada bagian sebelumnya, di mana secara garis besar 1 Timotius 4:12 dapat dibagi ke dalam dua bagian, maka dalam uraian tafsirannya akan difokuskan juga kepada pembagian tersebut.

Pertama, janganlah dia memandang rendah masa mudamu. Menurut Philip W. Towner, may compare his age to Paul's, or to that of older people in the church over whom he would exercise delegated apostolic authority (1Tim. 5:1). In any case, if the noun translated 'youth, state of youthfulness' is a reference to

11 Bruce M. Metzger, A Textual Commentary On The Greek New Testament, Second. (USA: United Bible Societies, 1994), 574. 
an age group, Timothy would probably have been less than forty years old. Attemps at greater precision are speculative since we do not know his age at the time he was called. But the possibility that 'youth' means here simply 'younger than me' or 'younger than the elders in the church' should not be ruled out. Either way, the parallel in 1 Cor. 16:10-11 (Titus 2:15) suggests that Paul's practice of dispatching coworkers authorized to act in his place (instructing, disciplining) meant putting them into very ticklish ministry situations. In this case, the explicit reference to Timothy's youth adds the burden of crossing the cultural line of age veneration. ${ }^{12}$

Secara ringkas pendapat Towner di atas hendak menyatakan bahwa kemungkinan Paulus sedang membandingkan usia Timotius dengannya, atau dengan tua-tua dalam gereja yang kepadanya Timotius akan menjalankan otoritas kerasulan yang didelegasikan kepadanya (1Tim. 5:1). Bagaimanapun, jika kata benda yang diterjemahkan 'muda, keadaan awet muda' adalah referensi ke kelompok usia, dan Timotius mungkin berusia kurang dari empat puluh tahun. Upaya yang lebih tepat bersifat spekulatif karena kita tidak tahu usianya saat dia dipanggil menjadi pelayan. Tetapi kemungkinan bahwa 'pemuda' di sini hanya berarti 'lebih muda dari saya (Paulus)' atau 'lebih muda dari para penatua di gereja' tidak boleh dikesampingkan.

Ditambahkan oleh Towner, bagaimana pun juga, bagian ini paralel dengan 1 Korintus 16:10-11 (Titus 2:15) dan menunjukkan bahwa praktik Paulus dalam mengirim rekan kerja yang berwenang untuk bertindak menggantikannya (menginstruksikan, mendisiplinkan) berarti menempatkan mereka ke dalam situasi pelayanan yang sangat menggelitik. Dalam hal ini, referensi eksplisit ke masa muda Timotius menambah beban melintasi garis budaya pemujaan usia. Maksudnya, apabila dalam budaya tertentu harus mereka yang memiliki usia lebih tua yang berhak memberikan nasihat dan menjadi pemimpin. Namun dalam konteks ini, Paulus mencoba menerobos budaya tersebut dengan mengintruksikan kepada Timotius supaya dalam masa mudanya tidak pandang rendah oleh seseorang atau orang lain.

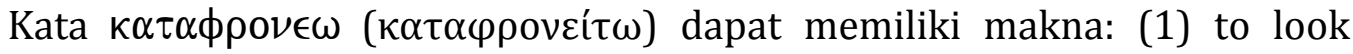
down on someone or something with contempt or aversion, with implication that one considers the object of little value, look down on, despise, scorn, treat with contempt; (2) to consider something not important enough to be an object of concern when evaluated against something, else, care, nothing for, disregard, be unafraid. ${ }^{13}$ Di mana dalam konteks 1 Timotius 4:12 cenderung lebih kepada makna yang pertama, yakni untuk menekankan tentang memandang rendah seseorang atau sesuatu dengan penghinaan atau kebencian, dengan implikasi bahwa seseorang menganggap objek bernilai kecil, memandang rendah, meremehkan, mencemooh, memperlakukan dengan jijik.

Dalam hal ini, Paulus tidak menghendaki Timotius dipandang demikian hanya karena dia masih muda.

12 Philip H. Towner, The New International Commentary on The New Testament: The Letters to Timothy and Titus (Michigan, USA: William B. Eerdmans Publishing Company, 2006), 314.

13 Walter Bauer's, A Greek-English Lexicon of The New Testament And Other Early Christian Literature (BDAG) Third Edition., ed. Frederick William Danker. (Chicago: The University of Chicago Press, 2000), 529. 
Artinya dalam konteks ini sebenarnya Paulus menginginkan supaya Timotius memiliki otoritas yang sama dengan yang dimilikinya sebagai rasul dalam hal pengajaran kepada jemaat. Sekalipun, dia juga menyadari bahwa usia yang masih muda dapat menjadi penghambat atau masalah bagi Timotius. ${ }^{14}$ Oleh karena dalam memimpin jemaat tentunya dia akan diperhadapkan dengan budaya yang lebih memberikan kesempatan kepada mereka yang berusia tua untuk memberikan nasihat. Selain itu, dalam gereja juga terdapat penatua yang pastinya memiliki usia lebih tua atau senior daripada Timotius. Ditambah lagi bahwa Timotius merupakan sosok yang penuh kasih sayang (2 Tim. 1:4), tetapi juga sangat penakut (2 Tim. 1:7), sehingga ia memerlukan banyak nasihat pribadi agar tidak tergoda oleh nafsu orang muda (2Tim. 2:22), dan supaya jangan malu menyaksikan Injil (2Tim. 1:8). ${ }^{15}$ Itulah sebabnya, Timotius sangat membutuhkan nasihat, motivasi untuk menaikkan kepercayaan dirinya bahkan keberaniannya untuk memberitakan Injil dalam jemaat.

Kedua, jadilah contoh orang-orang percaya dalam perkataan, dalam tingkah laku, dalam kasih, dalam kesetiaan, dalam kesucian. Bagian kedua ini merupakan syarat yang harus dipenuhi oleh Timotius supaya tidak disepelehkan dan pandang rendah oleh orang lain karena usianya masih muda. Dalam hal ini, dia harus menjadi teladan atau contoh bagi orang percaya. Menurut Towner, to overcome any associated with youth, Paul urges Timothy to become an 'example for the believers' (Titus 2:7). The task of modeling was intrinsic both to formal and informal ancient education. Paul assumed this role in relation to Timothy (1Cor. 4:17) and within the churches (Phil. 3:17; 1Thess. 1:7; 2 Thess. 3:9), and in these letters to delegates, Timothy and Titus were to do same (Titus 2:7). ${ }^{16}$

Artinya, untuk mengatasi segala masalah yang berhubungan dengan usia muda, maka Paulus mendesak Timotius untuk menjadi 'teladan bagi orang percaya' (Tit. 2:7). Tugas menjadi model adalah unsur utama dalam pendidikan kuno baik formal maupun informal. Paulus mengambil peran ini dalam hubungannya dengan Timotius (1Kor. 4:17) dan di dalam gereja-gereja (Flp. 3:17; 1 Tes. 1:7; 2 Tes. 3:9), dan dalam surat-surat ini kepada para delegasi, Timotius dan Titus melakukan hal yang sama (Tit. 2:7). Artinya Paulus menasihati Timotius supaya menjadi model atau contoh bagi orang percaya, dan sama halnya dengan Titus, maka Timotius juga harus menjadi pemimpin jemaat yang dapat menjadi teladan. Ditambahkan oleh Towner, to be a model or set example meant more than simply presenting a pattern that others were to mimic: the more a life is moulded by the word, the more it becomes typos, a model or mould. It was a case of living out life as faith in the gospel had shaped it. ${ }^{17}$

Pertanyaannya, teladan dalam hal apa saja? Di sini, Paulus mengatakan lima aspek keteladanan, yakni: dalam perkataan, dalam tingkah laku, dalam kasih, dalam kesetiaan, dalam kesucian. Menurut Paul M. Zehr, the first two

14 D.A. Carson;R.T. France; J.A. Motyer; G.J. Wenham., ed., Tafsiran Alkitab Abad Ke-21 (Matius-Wahyu) (Jakarta: YKBK/OMF, 2017), 558.

${ }^{15}$ Desti Samarenna and Harls Evan R Siahaan, "Memahami Dan Menerapkan Prinsip Kepemimpinan Orang Muda Menurut 1 Timotius 4: 12 Bagi Mahasiswa Teologi," BIA': Jurnal Teologi dan Pendidikan Kristen Kontekstual 2, no. 1 (2019): 1-13.

16 Towner, The New International Commentary on The New Testament: The Letters to Timothy and Titus, 314-15.

17 Ibid. 
qualities are exterior and the last three are interior. Timothy's outward life is to exemplify Christian behavior in speech and conduct. Paul wants Timothy to model Christian character through daily conversation and conduct and through teaching in the congregation. By modeling Christian character in speech and in conduct, Timothy's message will have integrity and authority. ${ }^{18}$

Maksudnya, dua kualitas (keteladanan) pertama adalah bersifat eksterior (kelihatan) dan tiga terakhir adalah interior (tidak kelihatan). Kehidupan lahiriah Timotius adalah untuk mencontohkan perilaku Kristen dalam berbicara dan tingkah laku. Paulus menginginkan Timotius menjadi teladan dalam karakter Kristen bahkan juga dalam percakapan dan tingkah laku dan melalui pengajaran dalam jemaat. Dengan keteladanan dan karakter orang Kristen dalam ucapan dan perilaku, maka pesan Timotius akan bersinggungan dengan integritas dan otoritas.

Ditambahkan oleh Zehr, conversation and conduct are followed by three interior qualities: love, faith, and purity. Some manuscripts add "in spirit," but the better reading omits it. Love and faith are common Pauline virtues (found in earlier epistles as well as in 1 Tim 1:5). Love is fraternal charity, giving oneself for the good of others. Faith means fidelity, trustworthiness, faithfulness. Paul could add hope as the third virtue, but here the third interior quality is purity. Purity may refer to sexual chastity (1 Tim 5:2). If so, we see here an implicit correction of some persons (1 Tim 5:11-15; 2 Tim 3:6). Purity also means integrity of heart (1 Tim 5:22). These three interior qualities give authenticity to the young leader's public ministry. Leaders like Timothy who model what they preach and teach are not intimidated by older persons and cultural norms, despite their youthfulness. ${ }^{19}$

Maksudnya, setiap perkataan dan tingkah laku yang merupakan keteladanan yang kelihatan harus diikuti oleh tiga kualitas batin, yaitu: kasih, iman, dan kemurnian. Beberapa manuskrip menambahkan "dalam roh", tetapi bacaan yang lebih baik menghilangkannya (lih. Pembahasan studi apparatus sebelumnya). Kasih dan iman adalah kebajikan umum Paulus (ditemukan dalam surat-surat sebelumnya serta dalam 1Tim. 1:5). Kasih adalah amal persaudaraan, memberikan diri sendiri untuk kebaikan orang lain. Iman berarti kesetiaan, dapat dipercaya, dan kesetiaan. Paulus dapat menambahkan harapan sebagai kebajikan ketiga, tetapi di sini kualitas batin yang ketiga adalah kemurnian. Kemurnian dapat merujuk pada kesucian seksual (1 Tim 5:2). Apabila demikian, di sini dilihat koreksi implisit dari beberapa orang (1 Tim 5:11-15; 2 Tim 3:6). Kesucian juga berarti keutuhan hati (1 Tim 5:22).

Intinya, di sini Paulus memberikan lima untuk kehidupan Kristen yang benar. Perkataan memang sangat penting, tetapi harus dihubungkan dengan tingkah laku, yakni perpaduan antara perkataan dan perbuatan yang benar. Pada perpaduan sifat lahiriah ini ditambahkan sifat batiniah, yakni kasih, kesetiaan dan kesucian. Inilah keteladanan yang lengkap dari hidup Kristen yang benar. ${ }^{20}$

Dengan demikian, kombinasi antara dua kualitas lahiriah dengan tiga kualitas batin ini akan memberikan kemurniannya pada pelayanan dalam jemaat yang digembalakan oleh Timotius sebagai pemimpin yang masih muda. Sehingga

18 Paul M. Zehr, Believers Church Bible Commentary: 1 \& 2 Timothy, Titus, ed. Douglas B. Miller and Loren L. Johns (Scottdale, Pennsylvania Waterloo, Ontario: Herald Press, 2001), 101.

19 Ibid, 101-102.

20 Wenham., Tafsiran Alkitab Abad Ke-21 (Matius-Wahyu), 558. 
setiap pemimpin atau anak muda seperti Timotius tidak terintimidasi oleh orang yang lebih tua dan norma budaya, meskipun mereka masih muda. Bahkan mereka dapat menjadi contoh dan teladan dalam pengajaran dan perkataan, termasuk juga dalam kasih, iman atau kesetiaan, dan dalam kemurnian atau kekudusan hidupnya.

\section{Penerapan Makna 1 Timotius 4:12 Terhadap Generasi Z}

Berdasarkan pemaparan tafsiran terhadap teks 1 Timotius 4:12 di atas dan membandingkan karakteristik atau ciri khas kehidupan generasi $\mathrm{Z}$ maka dijumpai adanya ketidaksinambungan. Sehingga apabila hendak menerapkan makna teks 1 Timotius 4:12 maka dituntut adanya perubahan yang signifikan dari kebiasaan hingga pola hidup generasi Z supaya dapat memenuhi standar rohani dan standar moral yang termaktub dalam teks 1 Timotius 4:12. Penerapan makna teks 1 Timotius 4:12 terhadap generasi Z diuraikan sebagai berikut. Perhatikan tabel di bawah ini!

\begin{tabular}{|c|c|c|}
\hline Makna 1 Timotius 4:12 & Karakteristik Generasi Z & Penerapan \\
\hline $\begin{array}{l}\text { Jangan ada yang } \\
\text { memandang rendah } \\
\text { masa mudamu, dalam hal } \\
\text { ini Timotius sebagai anak } \\
\text { muda namun sudah } \\
\text { diberikan tanggung } \\
\text { jawab dalam memimpin } \\
\text { dan mengajarkan jemaat } \\
\text { tentang ajaran Alkitab. }\end{array}$ & $\begin{array}{l}\text { Cenderung kurang } \\
\text { berotoritas dan } \\
\text { berintegritas. Hal ini tidak } \\
\text { terlepas dari kebiasaan } \\
\text { yang dilakukan tiap hari } \\
\text { yang terlalu sibuk dengan } \\
\text { dunia internet dan jarang } \\
\text { berinteraksi dengan orang } \\
\text { lain di sekitarnya. Bahkan } \\
\text { informasi yang terkadang } \\
\text { tidak terkontrol yang } \\
\text { diperolehnya dari internet } \\
\text { sedikit-banyak } \\
\text { memberikan pengaruh } \\
\text { yang negatif, sehingga } \\
\text { mendistorsi otoritas dan } \\
\text { integritasnya. }\end{array}$ & $\begin{array}{l}\text { Berdasarkan } \\
\text { pemaparan makna } \\
\text { teks } 1 \text { Timotius 4:12 } \\
\text { pada bagian } \\
\text { sebelumnya, maka } \\
\text { satu-satunya cara } \\
\text { supaya generasi Z } \\
\text { memperoleh } \\
\text { kepercayaan dan } \\
\text { dipandang mampu } \\
\text { memimpin adalah } \\
\text { dengan belajar Alkitab } \\
\text { sungguh-sungguh } \\
\text { untuk } \\
\text { mentransformasi } \\
\text { kehidupannya menjadi } \\
\text { pribadi yang memiliki } \\
\text { otoritas dan } \\
\text { berintegritas. }\end{array}$ \\
\hline $\begin{array}{l}\text { Paulus menginginkan } \\
\text { Timotius menjadi teladan } \\
\text { dalam karakter Kristen } \\
\text { bahkan juga dalam } \\
\text { perkataan dan tingkah } \\
\text { laku dan melalui } \\
\text { pengajaran dalam } \\
\text { jemaat. }\end{array}$ & $\begin{array}{l}\text { Cenderung memiliki } \\
\text { perkataan yang diucapkan } \\
\text { berdasarkan hasil } \\
\text { pengamatan di internet } \\
\text { yang seringkali tidak } \\
\text { mengedepankan etika, } \\
\text { kesopanan hingga } \\
\text { kepantasan. Karena } \\
\text { cenderung yang } \\
\text { diucapkan dan dilakukan } \\
\text { untuk kesenangan diri } \\
\text { dan kelompoknya. }\end{array}$ & $\begin{array}{l}\text { Untuk dapat } \\
\text { mengubah atau } \\
\text { memperbaiki karakter } \\
\text { yang tidak baik adalah } \\
\text { dengan membaca dan } \\
\text { belajar Alkitab dengan } \\
\text { sungguh-sungguh. } \\
\text { Sehingga melalui } \\
\text { pertolongan Roh } \\
\text { Kudus, kehidupan } \\
\text { generasi Z akan } \\
\text { diubahkan dan } \\
\text { tercermin lewat }\end{array}$ \\
\hline
\end{tabular}




\begin{tabular}{|l|l|l|}
\hline & & $\begin{array}{l}\text { perkataan dan tingkah } \\
\text { lakunya. }\end{array}$ \\
\hline $\begin{array}{l}\text { Setiap perkataan dan } \\
\text { tingkah laku yang } \\
\text { merupakan keteladanan } \\
\text { yang kelihatan harus } \\
\text { diikuti oleh tiga kualitas } \\
\text { batin, yaitu: kasih, iman, } \\
\text { dan kemurnian atau } \\
\text { kesucian. }\end{array}$ & $\begin{array}{l}\text { Generasi Z cenderung } \\
\text { meniru apa yang mereka } \\
\text { jumpai di dunia internet, } \\
\text { seperti: perbuatan yang } \\
\text { amoral, penyimpangan } \\
\text { seksual, hingga kebiasaan- } \\
\text { kebiasaan yang negatif. } \\
\text { Selain itu, kebiasaan } \\
\text { dengan dunia maya, } \\
\text { membuat mereka }\end{array}$ & $\begin{array}{l}\text { Apabila generasi Z } \\
\text { memiliki keteladanan } \\
\text { dalam kasih, iman dan } \\
\text { kesucian, maka sekali } \\
\text { lagi cara satu-satunya } \\
\text { adalah dengan } \\
\text { sungguh-sungguh } \\
\text { belajar Alkitab. Karena } \\
\text { hanya melalui cara } \\
\text { cenderung egois dan } \\
\text { egosentris dan sulit untuk } \\
\text { bersimpati terhadap } \\
\text { kesusahan dan }\end{array}$ \\
& $\begin{array}{l}\text { itulah Roh Kudus akan } \\
\text { pergumulan sesamanya. } \\
\text { Terakhir kepribadian } \\
\text { mentransformasi } \\
\text { hidup seseorang. }\end{array}$ \\
& $\begin{array}{l}\text { mereka cenderung labil } \\
\text { atau tidak stabil, mudah } \\
\text { berubah termasuk dalam } \\
\text { hal kepercayaan (iman). }\end{array}$ & \\
\hline
\end{tabular}

Penjelasan. Generasi Z sebagai anak muda dalam gejera masa kini pastinya diperhadapkan dengan persoalan yang serius perihal keteladanan. Mengapa? Karena dunia mereka membentuk sifat, karakter hingga kebiasaan yang membuat mereka "tidak" memiliki otoritas dan integritas. Selain itu faktor usia juga menjadi penentu. Dalam konteks Timotius, memang hal ini pula yang dalam pengamatan Paulus menjadi persoalan yang harus dibereskan - tetapi lebih disebabkan faktor usia yang masih muda. Itulah sebabnya solusi bagi persoalan ini adalah mengajak, membimbing, serta mengarahkan mereka untuk sungguhsungguh belajar Alkitab. Seperti yang dikemukakan oleh David G. Hagopian, orang yang mempelajari Alkitab memakai pikirannya untuk merepresentasikan dan mengaplikasikan kebenaran biblikal. ${ }^{21}$ Selain itu, melalui belajar Alkitab, maka Roh Kudus akan mengubah setiap karakter yang negatif dan sekaligus memberikan mereka otoritas serta berintegritas.

Selanjutnya dalam hal perkataan dan tingkah laku, maka generasi Z juga mengalami banyak kekurangan. Oleh karena akses langsung mereka ke internet untuk memperoleh informasi secara bebas tanpa adanya filterisasi yang baik sangat mempengaruhi cara mereka bertutur, cara mereka berpikir, hingga tingkah laku mereka. Sehingga cenderung apa yang mereka katakan dan lakukan selalu tidak sejalan dengan ajaran Alkitab. Dengan demikian, solusinya sekali lagi adalah mengajak, membimbing, serta mengarahkan mereka untuk sungguhsungguh belajar Alkitab.

Terakhir, sebagai anak muda maka generasi $\mathrm{Z}$ ini cenderung suka untuk meniru apa yang mereka jumpai dalam hidup mereka. Oleh karena mereka

21 David G. Hagopian Douglas J. Wilson, Douglas M. Jones III, Roger Wagner, Kembali Ke Dasar-Dasar: Menemukan Kembali Kebenaran Iman Reformed, ed. David G. Hagopian (Surabaya: Momentum, 2018), 5. 
sering mengakses internet secara bebas maka apa yang dijumpai di sana akan ditiru dan dilakukan. Sehingga tidak mengherankan apabila banyak dari generasi $\mathrm{Z}$ yang terjerumus ke dalam dosa seksual, dosa moral, dan kebiasaan-kebiasaan buruk yang lain. Selain itu, mereka juga cenderung egois dan egosentris, karena telah terbiasa asyik sendiri dengan dunia mereka dan tidak peduli dengan dunia sekitar. Hal ini pun kemudian membentuk kepribadian mereka menjadi kurang stabil dan tidak kokoh pada pendirian terutama berbicara tentang kepercayaan atau iman. Solusi untuk persoalan ketiga ini tetap sama dengan yang dua sebelumnya, yakni: mengajak, membimbing, serta mengarahkan mereka untuk sungguh-sungguh belajar Alkitab. Seperti yang dikemukakan oleh Jack Kuhatschek, saat kita melibatkan diri dengan Kitab Suci, tujuan kita adalah mengembangkan di dalam diri kita pikiran dan hati Allah. Kita ingin dapat memikirkan dan merespons setiap situasi dengan cara yang mungkin dilakukan Allah. ${ }^{22}$ Dengan demikian, generasi Z yang sungguh-sungguh belajar Alkitab akan mengerti hati dan pikiran Allah yang berisi tentang kasih, kekudusan, dan kesetiaan; untuk selanjutnya dipraktikkan dalam kehidupannya.

Perlu untuk digarisbawahi bahwa untuk membuat generasi $\mathrm{Z}$ menjadi pemimpin dan contoh atau teladan bagi orang lain, diperlukan peran dari berbagai pihak, khususnya pihak keluarga dalam hal ini orangtua, pihak gereja, dan pihak sekolah. Oleh karena tiga pihak inilah yang paling intens dan paling dekat bahkan mengenal kehidupan mereka secara praktis dan detail.

\section{Kesimpulan}

Berdasarkan uraian panjang lebar penelitian tentang makna teks 1 Timotius 4:12 dan penerapannya bagi generasi Z, maka diperoleh beberapa kesimpulan sebagai berikut:

Pertama, berdasarkan karakteristik dan ciri khas dari kehidupan generasi Z yang memiliki akses penuh kepada internet dan cenderung tidak memiliki filterisasi, maka hal itu dapat menimbulkan masalah yang cukup serius apabila tidak ada pendampingan dan pengawasan dari pihak orangtua, gereja dan sekolah. Untuk itulah perlu untuk meneliti teks 1 Timotius 4:12 guna menjadi rujukan dalam membina dan mendampingi generasi $\mathrm{Z}$.

Kedua, berdasarkan penelitian terhadap teks 1 Timotius 4:12, maka ditemukan makna bahwa sekalipun usia masih muda namun dengan eksisnya kualitas hidup yang berdasarkan kebenaran Alkitab akan menghasilkan otoritas dan integritas. Di mana hal itu akan membuat orang lain menghargai kehidupan anak muda, karena anak muda (generasi Z) telah memperlihatkan keteladanan dalam perkataan, tingkah laku, kasih, iman dan kesucian hidup. Bahkan dari penelitian ini juga diperoleh informasi bahwa keteladanan perkataan dan tingkah laku adalah keteladanan yang tampak atau kelihatan; sedangkan keteladanan kasih, iman dan kesucian merupakan keteladanan yang tidak kelihatan namun tidak dapat dipisahkan dari keteladanan yang kelihatan.

Ketiga, untuk dapat menerapkan makna teks 1 Timotius 4:12 dari kelompok generasi $\mathrm{Z}$ maka diperlukan perubahasan signifikan dari mereka. Di mana perubahan itu hanya dimungkinkan dengan mulai tekun dan rajin belajar dan membaca Alkitab supaya dapat mengubah dan memperbarui pola piker dan

22 Jack Kuhatschek, Menerapkan Alkitab Di Sepanjang Zaman (Jakarta: Literatur Perkantas, 2012), 29. 
pola hidup mereka sekaligus menjadi filterisasi terhadap contoh-contoh yang tidak baik yang diperoleh dari internet.

\section{Referensi}

Aulia Adam. "Selamat Tinggal Generasi Milenial, Selamat Datang Generasi Z." Tirto.Id. Last modified 2017. Accessed July 9, 2021. https://tirto.id/selamattinggal-generasi-milenial.

Barbara Aland, Kurt Aland, Johannes Karavidopoulos, Carlo M. Martini, Bruce M. Metzger, ed. Novum Testamentum Graece. 28th ed. Stuttgart, Germany: Deutsche Bibelgesellschaft, 2012.

Bauer's, Walter. A Greek-English Lexicon of The New Testament And Other Early Christian Literature (BDAG) Third Edition. Edited by Frederick William Danker. Chicago: The University of Chicago Press, 2000.

Craig L. Blomberg, Jennifer Foutz Markley. New Testament Exegesis: Panduan Komprehensif Eksegesis Kitab-Kitab Perjanjian Baru. Malang: Gandum Mas, 2018.

Douglas J. Wilson, Douglas M. Jones III, Roger Wagner, David G. Hagopian. Kembali Ke Dasar-Dasar: Menemukan Kembali Kebenaran Iman Reformed. Edited by David G. Hagopian. Surabaya: Momentum, 2018.

J. Ed. Komoszewski, M.James Sawyer, Daniel B. Wallace. Reinventing Jesus: Bagaimana Para Pemikir Skeptis Keliru Memahami Yesus Dan Menyesatkan Budaya Populer. Jakarta: Perkantas, 2011.

Kuhatschek, Jack. Menerapkan Alkitab Di Sepanjang Zaman. Jakarta: Literatur Perkantas, 2012.

Metzger, Bruce M. A Textual Commentary On The Greek New Testament. Second. USA: United Bible Societies, 1994.

Samarenna, Desti, and Harls Evan R Siahaan. "Memahami Dan Menerapkan Prinsip Kepemimpinan Orang Muda Menurut 1 Timotius 4: 12 Bagi Mahasiswa Teologi." BIA': Jurnal Teologi dan Pendidikan Kristen Kontekstual 2, no. 1 (2019): 1-13.

Towner, Philip H. The New International Commentary on The New Testament: The Letters to Timothy and Titus. Michigan, USA: William B. Eerdmans Publishing Company, 2006.

Wenham., D.A. Carson;R.T. France; J.A. Motyer; G.J., ed. Tafsiran Alkitab Abad Ke21 (Matius-Wahyu). Jakarta: YKBK/OMF, 2017.

Yustisia, Natali. “Teori Generasi." Perbanas Institute. Last modified 2016. Accessed July 9, 2021. https://dosen.perbanas.id/teori-generasi/.

Zega, Yunardi Kristian. "Pendidikan Agama Kristen Dalam Keluarga: Upaya Membangun Spiritualitas Remaja Generasi Z." JURNAL LUXNOS 7, no. 1 (2021): 105-116.

Zehr, Paul M. Believers Church Bible Commentary: 1 \& 2 Timothy, Titus. Edited by Douglas B. Miller and Loren L. Johns. Scottdale, Pennsylvania Waterloo, Ontario: Herald Press, 2001.

“GEN Z: KONSUMEN POTENSIAL MASA DEPAN." Nielsen.Com. Last modified 2016. Accessed July 9, 2021. https://www.nielsen.com/id/en/pressreleases/2016/GEN-Z-KONSUMEN-POTENSIAl-MASA-DEPAN/.

“Generasi Z." Wikipedia. Last modified 2020. Accessed July 9, 2021. https://id.wikipedia.org/wiki/Generasi_Z. 